\title{
The Effect of Bacterial Concentration on the Uptake of Labelled Arginine and Glucose by Escherichia coli
}

\author{
By SHYAMALA RAO AND P. M. BHARGAVA \\ Regional Research Laboratory, Hyderabad-9, A.P., India
}

(Received 16 February 1965)

\begin{abstract}
SUMMARY
In a non-growing population of an arginine-requiring auxotroph of Escherichia coli, the uptake of $\left[{ }^{14} \mathrm{C}\right]$ arginine and $\left[{ }^{14} \mathrm{C}\right]$ glucose by the whole organisms, and the incorporation of $\left[{ }^{14} \mathrm{C}\right]$ arginine in the acid-soluble fraction and total protein of the organisms, decreased with increasing bacterial concentration in a wide range $(0 \cdot 1-3 \cdot 0 \mathrm{mg}$. dry wt. bacteria/ml.). It is concluded that the rate of transport/organism of arginine and glucose decreased with increasing bacterial concentration.
\end{abstract}

\section{INTRODUCTION}

In suspensions of several mammalian cell types (spermatozoa, reticulocytes, hepatic cells), the rate of incorporation of labelled amino acids into protein has been shown to decrease with increasing cell concentration (Bhargava, Bishop \& Work, 1959; Bhargava \& Bhargava, 1962; Bhargava, 1964; Bhargava \& Bhargava, unpublished). With hepatic cell suspensions, this 'cell concentration effect' resulted from decreased permeability, due to enhanced cell contact with increasing cell concentration (Bhargava \& Bhargava, 1962; Bhargava, 1964; Bhargava \& Bhargava, unpublished). In the present paper we report experiments which show that in a resting population of an arginine-requiring auxotroph of Escherichia coli, E. coli 160-37, the rate of transport of $\left[{ }^{14} \mathrm{C}\right]$ arginine and $\left[{ }^{14} \mathrm{C}\right]$ glucose decreased as the bacterial concentration increased. This effect was more marked at lower than at higher bacterial concentrations. The results suggest that intercellular reactions may affect the rate of transport of nutrients in bacteria and thus indirectly influence intracellular metabolic activity.

\section{METHODS}

Organism. Escherichia coli $160-37$, which requires either arginine or ornithine as a nutrient, was used. It was maintained on nutrient agar slopes. The organism was incubated statically at $35^{\circ}$ in the following medium: $\mathrm{NH}_{4} \mathrm{Cl}, 0 \cdot 5 \mathrm{~g}$.; $\left(\mathrm{NH}_{4}\right)_{2} \mathrm{SO}_{4}$, 0.5 g.; $\mathrm{KH}_{2} \mathrm{PO}_{4}$, 13.6 g.; $\mathrm{MgSO}_{4}, 20 \mathrm{mg}$.; $\mathrm{Fe}\left(\mathrm{NH}_{4}\right)_{2}\left(\mathrm{SO}_{4}\right)_{2} \cdot 6 \mathrm{H}_{2} \mathrm{O}, 15 \cdot 6 \mathrm{mg}$.; glucose, 20 g.; L-arginine hydrochloride, $0 \cdot 1 \mathrm{~g}$; ; water to $1 \mathrm{l}$. The above medium without glucose and arginine is referred to subsequently as 'arginine and glucose-free (AGF)' medium.

Radioactive chemicals. Universally labelled $\left[{ }^{14} \mathrm{C}\right] \mathrm{L}$-arginine and $\left[{ }^{14} \mathrm{C}\right]$ glucose were obtained from the Radiochemical Centre, Amersham, Bucks, U.K.; they were diluted to the required specific activity with the unlabelled (reagent or analytical grade) analogue. 
Incubation with the labelled compounds and the isolation of dry organisms. Bacteria from an exponentially growing culture (usually towards the end of the logarithmic growth phase) were harvested, washed twice in the cold with the AGF medium and then pre-incubated for $30 \mathrm{~min}$. at $35^{\circ}$, without shaking, in the same medium. The bacteria were removed by centrifugation in the cold and resuspended in the AGF medium to give a slurry which was dispensed in a series of flasks (one for each bacterial concentration and each time point) which contained the appropriate amount of the AGF medium and the labelled compound to give the desired concentration of bacteria and compound in a total volume of 30-50 ml. The flasks were then incubated statically at $35^{\circ}$. At the end of the desired period, a set of flasks (one for each bacterial concentration) was removed and the contents centrifuged immediately in the cold. The deposited bacteria were washed in the cold, three times with the AGF medium containing a large excess of the unlabelled compound and once with distilled water. The washed bacteria were dried to constant wt. at $110^{\circ}$. There was no change in the extinction $\left(E_{750}\right)$ or in the $\mathrm{pH}$ value of the bacterial suspension before and after incubation with labelled precursor compound.

Isolation of the acid-soluble fraction. Trichloroacetic acid (TCA, 10\%) was added in the cold to bacteria washed as above after incubation with the labelled precursor. The precipitate was removed by centrifugation and washed twice with $5 \%$ TCA in the cold. All the TCA supernatant fluids were combined and the TCA removed by repeated extraction with ether. The aqueous fraction was evaporated to dryness. The residue obtained in this way was taken to contain all the free arginine and glucose (and their acid-soluble small molecular weight derivatives) of the bacteria.

Isolation of proteins. The washed TCA-precipitate of the bacteria, obtained as above, was treated with $5 \%$ TCA at $90^{\circ}$ for $30 \mathrm{~min}$. to remove nucleic acids. TCA was removed by centrifugation and the sediment washed once with $5 \%$ TCA. Lipids were removed from the residue in the usual way by treatment with organic solvents to give lipid-free and nucleic acid-free total protein of the bacteria. In some experiments the protein was isolated by treatment of the washed bacteria with $95 \%$ ethanol in water at room temperature. Lipids were removed from the ethanol-insoluble precipitate in the usual way. Nucleic acids were not removed from the protein fraction isolated in this way.

Measurement of radioactivity. The acid-soluble fraction was plated as a solution in $40 \%(\mathrm{v} / \mathrm{v})$ ethanol in water, and the dry bacteria and protein as a slurry in $40 \%(\mathrm{v} / \mathrm{v})$ ethanol in water on $2 \mathrm{~cm} .^{2}$ aluminium planchets which were counted in a Phillips Geiger-Müller end-window counter with an efficiency of $6 \%$ for ${ }^{14} \mathrm{C}$. Appropriate correction was made for self-absorption where necessary. In experiments on the incorporation of $\left[{ }^{14} \mathrm{C}\right]$ arginine and $\left[{ }^{14} \mathrm{C}\right]$ glucose, a radioactivity of about 100 and 10 counts/min./mg. dry wt. bacteria, respectively, was obtained in the $0 \mathrm{hr}$ samples. This radioactivity did not vary with concentration of bacteria and represented a small percentage of the incorporation obtained at the longer times. The $0 \mathrm{hr}$ radioactivity has not been subtracted from the values reported for subsequent time points. 


\section{RESULTS \\ Uptake of $\left.{ }^{[14} \mathrm{C}\right]$ arginine}

The total uptake of labelled arginine by whole bacteria proceeded linearly for about 30-60 min. after which it levelled off (Fig. 1). The period of linear uptake increased with decreasing concentration of bacteria. The rate of uptake also depended on the bacterial concentration; at any time point, progressively lesser amounts of $\left[{ }^{14} \mathrm{C}\right]$ arginine were taken up per bacterium as the bacterial concentration increased (Fig. 2).

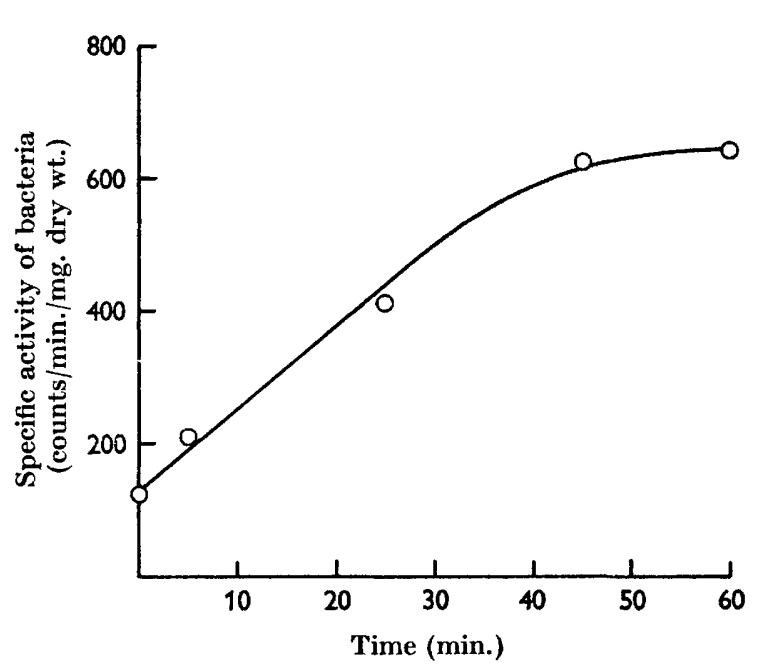

Fig. 1

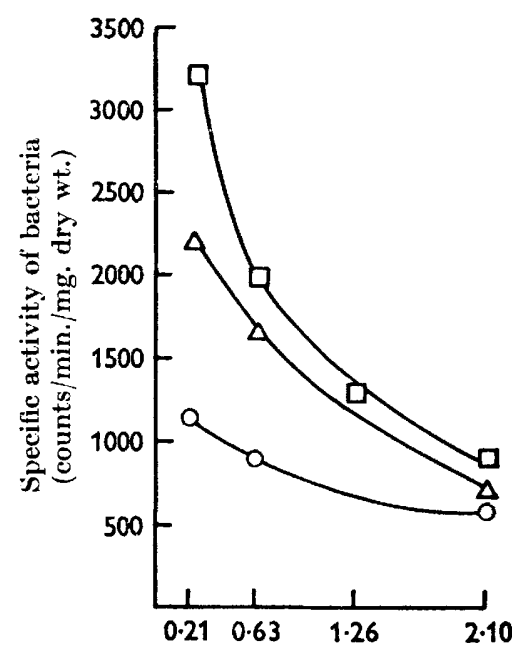

Mg. dry wt. of bacteria $/ \mathrm{ml}$. of incubation medium

Fig. 2

Fig. 1. Incorporation of [ $\left.{ }^{14} \mathrm{C}\right]$ arginine into organisms of a non-multiplying population of Escherichia coli 160-37. The concentration of bacteria was equivalent to $0.9 \mathrm{mg}$. dry wt. bacteria/ml. The bacteria were pre-incubated for $30 \mathrm{~min}$. in an arginine-free and glucosefree salts solution before the addition of labelled arginine. The concentration of $\left[{ }^{14} \mathrm{C}\right]$ arginine was $100 \mu \mathrm{g}$. $(0.5 \mu \mathrm{C}$. $) / \mathrm{ml}$.

Fig. 2. Changes, with the concentration of bacteria, in the quantity of $\left.{ }^{14} \mathrm{C}\right]$ arginine taken up by the organisms of a non-multiplying population of Escherichia coli 160-37 on incubation with [ ${ }^{14} \mathrm{C}$ ]arginine. The bacteria were pre-incubated for $30 \mathrm{~min}$. in an arginine-free and glucose-free salt solution before addition of labelled arginine. The concentration of $\left[{ }^{14} \mathrm{C}\right]$ arginine was $100 \mu \mathrm{g} .(0.5 \mu \mathrm{C}.) / \mathrm{ml} . O, 25 \mathrm{~min} ; \Delta, 40 \mathrm{~min}$.; $\square, 60 \mathrm{~min}$.

The radioactivity in the bacteria, following uptake of $\left[{ }^{14} \mathrm{C}\right]$ arginine, would be expected to be primarily due to free arginine (or acid-soluble arginine derivatives) and arginine incorporated into protein due to protein turnover; the latter was shown (Mandelstam, 1958b) to occur to an extent of $5 \% / \mathrm{hr}$ in resting organisms of the strain of Escherichia coli used in the present work. The radioactivity in the acid-soluble fraction, as well as in the protein fraction derived from unit dry wt. of bacteria, decreased with an increase in the concentration of bacteria at all the times studied (Figs. 3, 4). The dependence of the above uptake on bacterial concentration was more marked at longer times than at shorter times, as in the case of the total 
uptake of $\left[{ }^{14} \mathrm{C}\right]$ arginine by the whole bacteria. The incorporation of $\left[{ }^{14} \mathrm{C}\right]$ arginine/ unit wt. protein also decreased as the concentration of bacteria in the suspension increased (Fig. 5).

\section{Uptake of glucose}

The rate of uptake of $\left[{ }^{14} \mathrm{C}\right]$ glucose by the bacteria also increased with decreasing concentration of bacteria (Fig. 6). As in the case of $\left[{ }^{14} \mathrm{C}\right]$ arginine uptake, the period for which the uptake of $\left[{ }^{14} \mathrm{C}\right]$ glucose proceeded linearly was longer at lower bacterial concentrations than at higher concentrations.

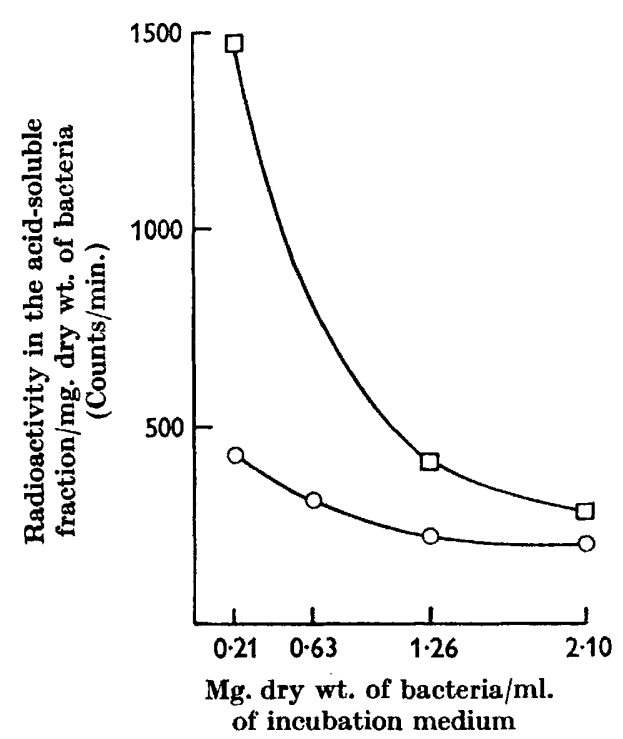

Fig. 3

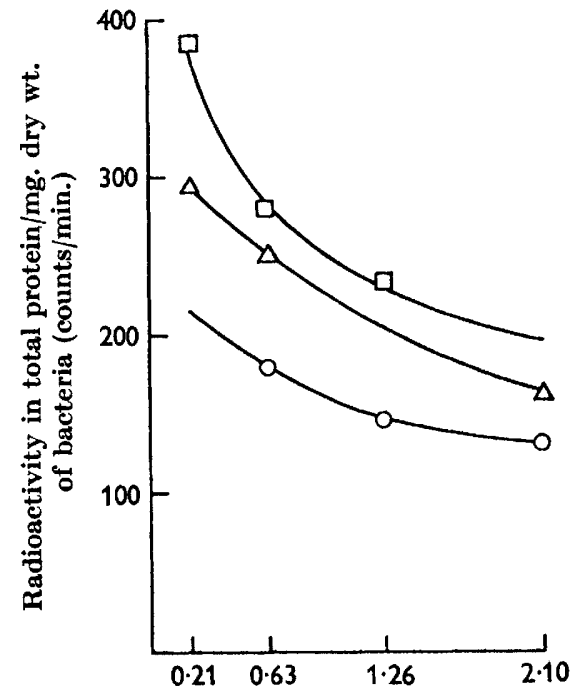

Mg. dry wt. of bacteria/ml. of incubation medium

Fig. 4

Fig. 3. Changes, with the concentration of bacteria, in the quantity of $\left.{ }^{14} \mathrm{C}\right]$ arginine accumulating in the acid-soluble fraction of a non-multiplying population of Escherichia coli 160-37 on incubation with [ ${ }^{14} \mathrm{C}$ ]arginine. The bacteria were pre-incubated for $30 \mathrm{~min}$. in an arginine-free and glucose-free salts solution before addition of labelled arginine. The concentration of $\left[{ }^{14} \mathrm{C}\right]$ arginine was $100 \mu \mathrm{g}$. (0.5 $\left.\mu \mathrm{C}.\right) / \mathrm{ml} .0,25 \mathrm{~min}$.; $\square, 60 \mathrm{~min}$.

Fig. 4. Changes, with the concentration of bacteria, in the radioactivity incorporated in the total protein of a non-multiplying population of Escherichia coli 160-37 on incubation with [ ${ }^{14} \mathrm{C}$ ]arginine. The bacteria were pre-incubated for $30 \mathrm{~min}$. in an arginine-free and glucose-free salts solution before addition of labelled arginine. The concentration of arginine was $100 \mu \mathrm{g}$. $(0.5 \mu \mathrm{C}$.) $/ \mathrm{ml}$. O, 25 min.; $\Delta, 40 \mathrm{~min}$.; $\square, 60 \mathrm{~min}$.

\section{DISCUSSION}

In the present work, the bacteria were washed free from medium and then star red of glucose and arginine for $30 \mathrm{~min}$. before either labelled arginine or labelled gluco.ie was added. There was no increase in the extinction of the culture during incubation with the labelled precursor. Further, the uptake of glucose was nearly the same as reported for the same strain of Escherichia coli $(E$. coli, 160-37) in the maximum stationary phase of growth during which no formation of new organisms (as adjudged by synthesis of DNA) was observed (Kashmiri \& Bhargava, 1965). It can, therefore, be concluded that there was no formation of new bacteria during the 
period of incubation with the labelled precursor. The results clearly show that in such a non-multiplying population, the quantity of labelled arginine taken up in 20-80 min. by a unit population of the bacteria or their acid-soluble fraction or
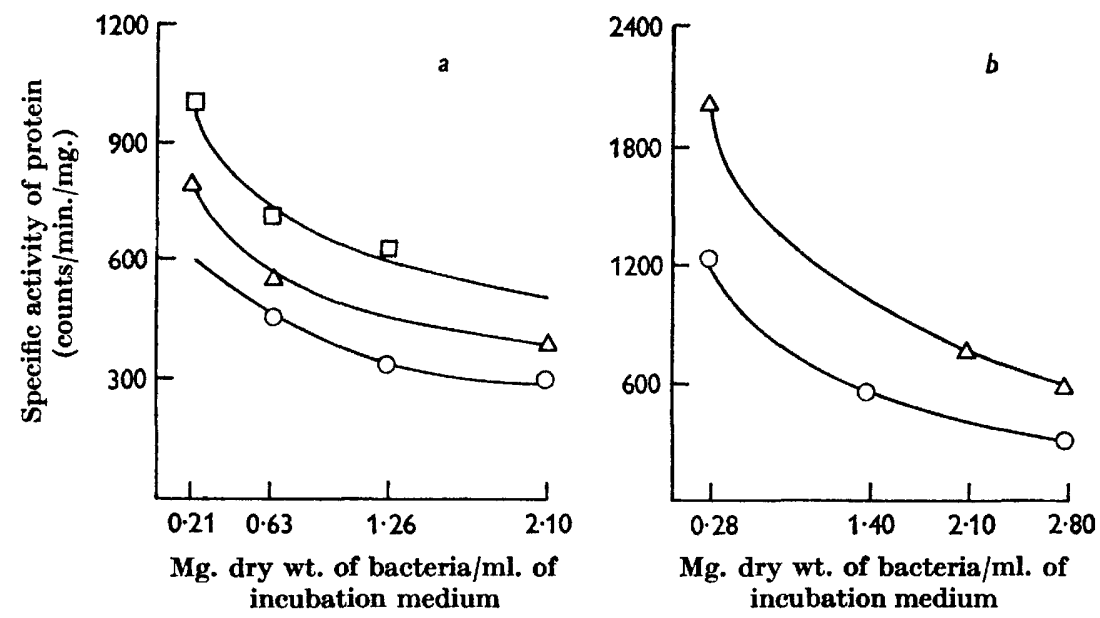

Fig. 5. Changes, with the concentration of bacteria, in the specific radioactivity of protein of a non-multiplying population of Escherichia coli 160-87 on incubation with [ ${ }^{14} \mathrm{C}$ ]arginine. The bacteria were pre-incubated for $30 \mathrm{~min}$. in an arginine-free and glucose-free salts solution before addition of labelled arginine. The concentration of $\left[{ }^{14} \mathrm{C}\right]$ arginine was $100 \mu \mathrm{g}$. $\quad(0.5 \mu \mathrm{C}.) / \mathrm{ml}$. The two figures $a$ and $b$ correspond to two different experiments. (a) $O, 25 \mathrm{~min}$.; $\triangle, 40 \mathrm{~min}$; $\square, 60 \mathrm{~min}$. In this experiment, the protein was isolated after treatment of the whole bacteria with TCA. (b) $\bigcirc, 30$ min.; $\triangle, 80 \mathrm{~min}$. In this experiment, the protein was isolated following treatment of the whole bacteria with $95 \%(v / v)$ ethanol in water.

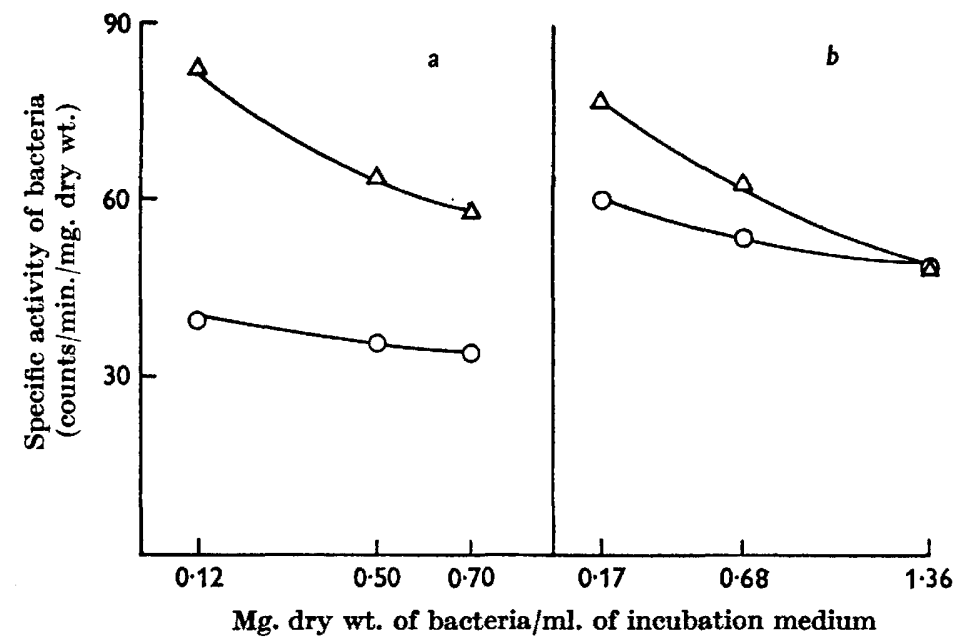

Fig. 6. Changes, with the concentration of bacteria, in the quantity of $\left.{ }^{14} \mathrm{C}\right]$ glucose taken up by the organisms of a non-multiplying population of Escherichia coli 160-37 on incubation with $\left[{ }^{14} \mathrm{C}\right]$ glucose. The bacteria were pre-incubated for $30 \mathrm{~min}$. in an arginine-free and glucose-free salts solution before the addition of labelled glucose. The concentration of [14 C]glucose was $20 \mathrm{mg}$. (1 $\mu \mathrm{C}$.)/ml. The two figures $a$ and $b$ correspond to two different experiments. (a) $O, 15$ min.; $\triangle, 45$ min.; (b) $\bigcirc, 45$ min.; $\triangle, 75 \mathrm{~min}$. 
protein, varied inversely with the concentration of bacteria. Such an inverse relationship might be due to a decrease in the specific radioactivity of extracellular arginine and/or a decrease in the rate of transport of arginine from the extracellular medium into the organisms, with increasing bacterial concentration.

The bacteria might secrete unlabelled arginine released as a result of intracellular protein turnover of $2-7 \% / \mathrm{hr}$ which has been shown to occur in resting populations of bacteria and yeasts deprived of an essential nutrient (Mandelstam, 1957, 1958 $b$; Halvorson, 1958; Borek, Ponticorvo \& Rittenberg, 1958; Urba, 1959; Mandelstam \& Halvorson, 1960; Proctor, 1962). In such an event, increasing amounts of unlabelled arginine would be secreted with increasing bacterial concentration; this would cause the specific radioactivity of the arginine of the medium at any time point to decrease as the bacterial concentration increased. However, if it be assumed that the protein content of the bacteria is $75 \%$, that the protein contains $10 \%$ arginine and that the protein turnover in the resting state is $5 \% / \mathrm{hr}$ (Mandelstam, $1958 \mathrm{~b}$ ), it can be calculated that the amount of unlabelled arginine released in $1 \mathrm{hr}$ from the maximum concentration of bacteria used (equiv. $2 \cdot 8 \mathrm{mg}$. dry wt. bacteria $/ \mathrm{ml}$.) could not exceed $10 \mu \mathrm{g} . / \mathrm{ml}$. culture medium. In fact, it has been shown that non-dividing Escherichia coli in which protein synthesis is blocked secrete amino acids to an extent of only $5 \mu \mathrm{g} . / \mathrm{mg}$. dry wt. bacteria/hr (Mandelstam, $1958 a$ ). The quantity of arginine found in the present work to be secreted by the bacteria could not therefore be sufficient to alter substantially the specific activity of the extracellular labelled arginine present initially in the medium (100 $\mu \mathrm{g} . / \mathrm{ml}$.). This rules out the possibility that the observed effect of bacterial concentration might be due to secretion of unlabelled arginine by the bacteria and consequential decrease in the specific radioactivity of extracellular arginine.

It would, therefore, appear that there was a decrease in the rate of transport of arginine per bacterium, measured over a period of 20-60 min., as the concentration of bacteria increased. The reasons for this decrease are not clear. The obvious possibility that arginine became limiting at the higher bacterial concentrations is ruled out by the following considerations. The initial concentration of $\left[{ }^{14} \mathrm{C}\right]$ arginine in the medium was $100 \mu \mathrm{g}$. $\left(1 \cdot 11 \times 10^{6}\right.$ disintegrations or 67,000 counts $/ \mathrm{min}$. $) / \mathrm{ml}$.; from this and the data of Fig. 2 it can be calculated that at the lowest bacterial concentration (equiv. $0 \cdot 21 \mathrm{mg}$. dry wt. bacteria/ml.), just $1 \mu \mathrm{g} .(1 \%)$ of the labelled arginine was taken up by the bacteria/ml. medium in $60 \mathrm{~min}$. This implies that only $10 \%$ of the $\left[{ }^{14} \mathrm{C}\right]$ arginine contained originally in the medium would have been consumed in $60 \mathrm{~min}$., had the bacteria at the maximum concentration of equiv. 2.1 mg. dry wt. bacteria/ml. used in most experiments taken up labelled arginine at the same rate as was taken up by the bacteria at the lowest bacterial concentration used. The actual uptake of arginine by the bacteria at this concentration (equiv. $2.1 \mathrm{mg}$. dry wt. bacteria $/ \mathrm{ml}$.) in $60 \mathrm{~min}$. was only $3 \%$ of the $\left[{ }^{14} \mathrm{C}\right]$ arginine present originally in the medium (Fig. 2). Thus, the concentration of arginine in the medium was sufficiently high to allow it to stay practically unchanged in $60 \mathrm{~min}$. at all bacterial concentrations studied. The results obtained with $\left[{ }^{14} \mathrm{C}\right]$ glucose (Fig. 6), which was present in the medium at $20 \mathrm{mg}$. $/ \mathrm{ml}$., also indicate that the decrease in the rate of transport of the nutrients obtained with increasing bacterial concentration was not due to this nutrient becoming limiting.

One possibility would be that contact between bacteria, the frequency and 
extent of which would increase with increasing bacterial concentrations, might decrease the permeability of the cell surface to some nutrients for the duration of the contact. In several mammalian cell systems cell contact has been shown to influence the visible movement of the membrane (Abercrombie \& Ambrose, 1958) and it is conceivable that it may also affect the functional activity of the membrane in respect of the transport of nutrients. A cell concentration effect similar to that reported here for Escherichia coli has been observed with mammalian cell suspensions (Bhargava et al. 1959; Bhargava \& Bhargava, 1962; Bhargava, 1964).

The authors are grateful to Dr J. Mandelstam for a gift of the culture of Escherichia coli 160-37 used in this work, and to Dr S. Husain Zaheer, Director-General, Council of Scientific and Industrial Research, New Delhi, and Dr G. S. Sidhu, Director of this Laboratory, for encouragement.

\section{REFERENCES}

Abercrombie, M. \& Ambrose, E. J. (1958). Interference microscope studies of cell contacts in tissue culture. Exp. Cell Res. 15, 332.

BhaRgava, K. (1964). Some studies on the biochemical and physiological properties of liver cells in suspensions. Ph.D. dissertation, submitted to Banaras Hindu University, Varanasi, India.

Bhargava, K. \& Bhargava, P. M. (1962). The incorporation of labelled amino acids into the proteins of liver cells in suspension. Life Sci. p. 477.

Bhargava, P. M., Bishop, M. W. H. \& Work, T. S. (1959). Incorporation of $\left({ }^{14} \mathrm{C}\right)$-amino acids into the proteins of bull spermatozoa. Biochem. J. 73, 247.

Borek, E., Ponteconvo, L. \& Rittenberg, D. (1958). Protein turnover in microorganisms. Proc. nat. Acad. Sci., Wash. 44, 369.

Halvorson, H. (1958). Intracellular protein and nucleic acid turnover in resting yeast cells. Biochim. biophys. Acta, $27,255$.

Kashmiri, S. V.S. \& Bhargava, P. M. (1965). Incorporation of labelled glucose, phosphate and orotic acid in $E$. coli during the logarithmic and the maximum stationary phases of growth. $J$. Bact. (in the press).

Mandelstam, J. (1957). Turnover of protein in starved bacteria and its relationship to the induced synthesis of enzyme. Nature, Lond. 179, 1179.

MANDELSTAM, J. (1958a). The free amino acids in growing and non-growing populations of Escherichia coli. Biochem. J. 69, 103.

MANDELSTAM, J. (1958b). Turnover of protein in non-growing populations of Escherichia coli. Biochem. J. 69, 110.

Mandelstam, J. \& Halvorson, H. (1960). Turnover of protein and nucleic acid in soluble and ribosome fractions of non-growing Escherichia coli. Biochim. biophys. Acta, 40, 43.

Proctor, M. H. (1962). Protein turnover in resting bacteria. Folia Microbiol. 7, 207.

Urba, R. C. (1959). Protein breakdown in Bacillus cereus. Biochem. J. 71, 513. 